\title{
Pengaruh Pengeluaran Zakat Perbankan, Ukuran Perusahaan dan Islamic Social Responsibility (ISR)Terhadap Profitabilitas pada Bank Umum Syariah di Indonesia Periode 2016-2019
}

\author{
Eliana ${ }^{1}$, Intan Novia Astuti ${ }^{2}$, Nurbismi ${ }^{3}$, Akmal Riza ${ }^{4}$ \\ 1,2,3 Prodi Akuntansi dan Manajemen, STIES Banda Aceh, Indonesia. \\ ${ }^{4}$ Fakultas Ekonomi Bisnis Islam, UIN Ar-Raniry, Banda Aceh, \\ Indonesia.
}

\begin{abstract}
Abstrak. Penelitian ini bertujuan untuk melihat pengaruh pengeluaran zakat perbankan, ukuran perusabaan dan Islamic Social Responsibility terhadap profitabilitas. Data penelitian ini menggunakan data laporan keuangan Annual Report atau laporan tabunan masing-masing Bank Umum Syariah periode 2016-2019. Penelitian ini menggunakan metode pendekatan penelitian kuantitatif dengan metode analisis data menggukan model regresi linier berganda. Pengujian hipotesis dilakukan dengan uji statistik yaitu uji parsial (uji-t) dan uji simultan (uji-F) dengan tingkat signifikansi 5\%. Hasil uji secara simultan menunjuk.kan babwa pengeluaran zakat perbankan, ukuran perusahaan dan ISR secara simultan berpengaruh positif dan signifikan terhadap profitabilitas. Secara parsial variabel pengeluaran zakat perbankan berpangarub positif dan signifikan terbadap profitabilitas, sedangkan variabel ukuran perusahaan dan ISR tidak berpengaruh terhadap profitabilitas pada Bank Umum Syariah.
\end{abstract}

Kata kunci: Pengeluran Zakat, Ukuran Perusahaan, ISR, Profitabilitas.

\begin{abstract}
This study aims to see the effect of banking zakat expenditure, company size and Islamic Social Responsibility on profitability. The data of this research uses the financial report data Annual Report or the annual report of each Islamic Commercial Bank for the period 2016-2019. This study uses a quantitative research approach with data analysis methods using multiple linear regression models. Hypothesis testing is done by statistical tests, namely partial test (t-test) and simultaneous test (F-test) with a significance level of 5\%. Simultaneous test results show that banking rakat expenditure, company size and ISR simultaneously have a positive and significant effect on profitability. Partially, the bank zakat expenditure variable has a positive and significant impact on profitability, while the company size variable and ISR have no effect on profitability at Islamic Commercial Banks.
\end{abstract}

Keywords: Zakat Expenditures, Company Size, ISR, Profitability. 


\section{Pendahuluan}

Perbankan syariah di Indonesia saat ini berkembang sangat pesat, ini dapat dilihat dari data statistik perbankan syariah tahun 2019 dimana jumlah Bank Umum Syariah (BUS) semakin meningkat setiap tahunnya.

Tabel 1 Perkembangan BUS di Indonesia

\begin{tabular}{lcccc}
\hline & \multicolumn{4}{c}{ Tahun } \\
& 2016 & 2017 & 2018 & 2019 \\
\hline BUS & 13 & 13 & 14 & 14 \\
Kantor Bus & 1869 & 1825 & 1875 & 1885 \\
UUS & 21 & 21 & 20 & 20 \\
BPRS & 166 & 167 & 167 & 165 \\
\hline
\end{tabular}

Dilihat dari tabel 1, perkembangan perbankan syariah di Indonesia semakin meningkat, semestinya dalam segi kinerja, juga harus mampu meningkatkan kinerjanya, dan ini berimplikasi pada semakin besarnya tantangan yang harus dihadapi, untuk mempertahankan citra dan nama baik di mata nasabah agar tetap menjaga kepercayaan serta loyalitas nasabah terhadap bank Syariah (Falikhatum dan Assegaf, 2012).

Laba atau keuntungan merupakan gambaran mengenai kinerja yang diperoleh dari proses transaksi umum yang dilakukan perusahaan selama periode tertentu. Laba dijadikan sebagai tolak ukur oleh para stakeholder untuk menilai sejauh mana kinerja manajemen dalam mengelola suatu perusahaan. Didalam penelitian ini profitabilitas digunakan sebagai alat ukur kinerja keuangan dengan mengunakan rasio Return On Assets (ROA) dan Return on Equity (ROE) (Septian, Amelia, Nur, 2012). Kenapa menggunakan ROA disebabkan Bank Indonesia (BI) adalah pegawas perbankan yang lebih mengunggulkan dana masyarakat sebagai asset di perbankan (Firmansyah dan Irman, 2013), sedangkan Return on Equity merupakan pengukuran dari penghasilan (income) yang bagi pemilik perusahaan (baik pemegang saham biasa maupun pemegang saham preferen) atas modal yang sudah mereka investasikan didalam perusahaan (Syamsuddin dan Lukman, 2009).

Terdapat hal yang lain yang perlu diperhatikan selain kinerja keuangan di BUS yaitu kinerja sosial, salah satunya adalah zakat dan IRS. BUS wajib mengeluarkan, menghimpun dan menyalurkan zakat perusahaan setiap tahun. dikarenakan zakat salah satu rukun Islam yang hukumnya wajib bagi setiap muslim yang merdeka dan memiliki harta kekayaan yang jumlah tertentu yang telah mencapai nisab (Ilmi dan Muhammad Bahrul, 2011). Zakat yang diwajibkan atas badan usaha tidak dimaksudkan untuk membebani badan usaha secara berlebihan dan mengancam keberlangsungan hidup perusahaan. Menurut Undang-undang Nomor 17 Tahun 2000, tentang Pajak Penghasilan, Pasal 4 ayat (3) disebutkan pengeluaran zakat dinyatakan sebagai pengurangan penghasilan kena pajak bagi pihak yang mengeluarkan zakat.

Permasalahan zakat di perbankan syariah seirama dengan permasalahan dana ISR yang ada diperbankan. Dimana masih banyaknya dana yang belum terealisasi kedalam bentuk-bentuk usaha riil, sehingga masyarakat atau nasabah belum merasakan jika perbankan juga memiliki fungsi dan tanggung jawab. Oleh karena itu, perlunya perbaikan, evaluasi, dan inovasi guna meningkatkan kepercayaan nasabah serta membuktikan bahwasanya bank syariah tidak hanya memiliki business oriented tetapi juga social responsibility yang nanti akan berpengaruh kepada citra dan akan meningkatkan laba perusahaan (Masruroh dan Nikmatulla, 2015)

Islamic Social Responsibility (ISR) merupakan mekanisme bagi suatu organisasi untuk secara sukarela mengintegrasikan perhatian terhadap lingkungan dan sosial kedalam operasi dan interaksinya dengan stakeholder yang melebihi tanggung jawab organisasi dibidang hukum. Program ISR pada Bank Umum Syariah yang disalurkan sangat beraneka ragam, mulai dari program sosial, kesehatan, pendidikan dan lain sebagainya, walaupun belum semuanya terealisasi dengan optimal. Penerapan ISR dipercaya juga dapat meningkatkan kinerja keuangan perusahaan, dimana investor cenderung menanamkan modal pada perusahaan yang melaksanakan aktivitas ISR yang akan meningkatkan laba yang lebih besar untuk keberlanjutan perusahaan (Arifin $\mathrm{dkk}$, 2016)

Ukuran perusahaan adalah faktor yang dapat diperhatikan dalam mengambil keputusan utang untuk dijalankan oleh perusahaan, ukuran perusahaan mencermikan besar dan kecil perusahaan, untuk melihat besar dan kecil 
perusahaan dapat ditentukan berdasarkan total penjualan, aset dan tingkat penjulan. Apabila jumlah aset yang dimiliki oleh perusahaan lebih besar, maka pendapatan yang didapat semakin meningkat velocity of money atau peredaran uang (Eliana, Nurhayati dan Ayumiati, 2020).

\section{Metodologi Penelitian}

\section{Populasi dan Sampel}

Populasi adalah keseluruhan subyek penelitian. menurut (Sugiyono, 2014) populasi adalah wilayah generalisasi yang terdiri atas objek atau subyek yang mempunyai kualitas dan karakteristik tentukan yang diterapkan oleh peneliti untuk dipelajari dan kemudian ditarik kesimpulannya. Yang menjadi populasi dalam penelitian ini adalah seluruh Bank Umum Syariah yang ada di Indonesia yang memiliki laporan keuangan yang telah di publikasi secara resmi baik oleh Bank Indonesia (BI) dan Otoritas Jasa Keuangan (OJK) yaitu selama periode 2016-2019 (Arikunto, dan Suharsimi, 2016). mengungkapkan bahwa sampel adalah sebagian atau wakil dari populasi yang diteliti. teknik pengambilan sampel dalam penelitian ini adalah nonprobabilitas. Teknik pengambilan sampel yang digunakan adalah purposive sampling biasa juga disebut dengan judmental sampling. Alasan menggunakan teknik purposive sampling adalah kerena tidak semua sampel memiliki kriteria yang sesuai dengan fenomena yang diteliti. Adapun kriteria sebagai berikut:

1. Sampel merupakan Bank Umum Syariah yang terdaftar di OJK dan telah memiliki izin operasioanal sebagai Bank Umum Syariah pada tahun 2016.

2. Perusahaan tersebut telah menerbitkan dan mempublikasikan secara resmi laporan keuangan (annual report) secara lengkap, yaitu laporan penggunaan dana zakat, ukuran perusahaan dan laporan program ISR selama periode yang dimaksud.

3. Adanya akses untuk memperoleh data laporan tahunan perusahaan yang bersangkutandalam website resmi Bank Umum Syariah tersebut.

Populasi yang memenuhi semua kriteria adalah Bank Muamalat Indonesia, Bank Victoria Syariah, Bank BRI Syariah, Bank Jabar Banten Syariah, Bank BNI Syariah, Bank Syariah
Mandiri, Bank Mega Syariah, BCA Syariah, Bank Syariah Bukopin, Bank Panin Dubai Syariah, dengan pengamatan 4 tahun dengan total sampel berjumlah 40 bulan.

\section{Operasional Variabel}

Profitabilitas sebagai variabel dependen, dengan menggunakan rasio ROA dan ROE sebagai indikator yang digunakan untuk mengukur keberhasilan usaha yang dijalankan. rumus untuk menghitung ROA dan ROE adalah sebagai berikut:

$$
\begin{aligned}
\text { ROA } & =\frac{\text { Laba Sebelum Pajak }}{\text { Total Aset }} \times 100 \% \\
\text { ROE } & =\frac{\text { Laba Bersih }}{\text { Total Ekuitas }} \times 100 \%
\end{aligned}
$$

Return On Assets (ROA) dipakai untuk mengevaluasi apakah manajemen telah mendapat imbalan yang memadai (reasobable return) dari aset yang dikuasai. Return on Equity (ROE) adalah rasio yang menunjukkan tingkat pengembalian yang diperoleh pemilik bisnis dari modal yang telah dikelurkan untuk bisnis tersebut.

Pengeluaran Zakat perbankan yang merupakan variabek independen adalah zakat yang dikenakan atas perusahaan yang menjalankan usahanya (dapat bertindak secara hukum, memiliki hak dan kewajiban, serta dapat memiliki kekayaannya sendiri). rumus untuk menghitung zakat menurut PSAK Nomor 109 tentang akuntansi zakat dan infaq/sedekah yang disahkan pada Mei 2008 oleh Dewan Standar Akuntansi Indonesia adalah sebagai berikut:

\section{Laba Setelah Pajak x 2,5\%}

Ukuran perusahaan merupakan skala pengukuran atas suatu perusahaan baik dari segi aset yang dimiliki perusahaan tersebut maupun unsur lainnya seperti jumlah tenaga kerja. Ukuran perusahaan juga merupakan faktor yang dapat diperhatikan dalam keberlansungan bisnis perusahaan, dengan ukuran perusahaan yang besar akan mudah mendapatkan modal, begitu juga dengan laba, perusahaan yang besar leba semakin sedikit karena dengan kapasitas perusahaan yang besar yang otomatis karyawann berjumlah besar, sehingga operasional yang dikeluarkan semakin besar.

Ukuran perusahaan diukur sebagai $\log$ dari nilai 
ekuitas pada akhir tahun dasar, mempunyai hubungan yang positif dan signifikan dengan probabilitas tindakan operasional dan restrukturisasi asset dengan menggunakan rumus sebagai berikut:

$$
\text { Size }=\log (\text { Total Aktiva })
$$

Variabel independen selanjutnya adalah Islamic Social Responsibility merupakan sebuah konsep pengungkapan ISR yang menekan pada pendekatan kerohanian sebagai dasar dari kewajiban perusahaan untuk memiliki tanggung jawab sosial kepada lingkungan sekitarnya, baik lingkungan alam maupun masyarakat (Agung \& Abdul, 2017). ISR ini dihitung dengan indeks pengungkapan yang salah satu standar pelaporan kinerja sosial perusahaan-perusahaan yang berbasis syariah ada 47 item dalam 6 kategori pengukapan yaitu keuangan dan investasi, produk dan service, karyawan (tenaga kerja), masyarakat, lingkungan, dan tata kelola perusahaan. selanjutnya yaitu melakukan scorring, masing-masing item pengungkapan memiliki nilai 0 dan 1 . Untuk 0 tidak ada pengungkapan, sedangkan 1 melakukan pengungkapan. Untuk melakukan pengungkapan ISR dengan mengunakan indeks Islamic Social Reporting:

ISR $=$ Lumlah Item yang diungkapkan

Jumlah Total Item pengungkapan

\section{Metode Analisis Data}

Penelitian ini menggunakan pendekatan kuantitatif berupa angka dan perhitungannya dengan metode statistik yaitu SPSS versi 20. Adapun metodenya adalah uji asumsi klasik, analisis regresi berganda, uji koefisien determinasi $\left(\mathrm{R}^{2}\right)$ dan pengujian hipotesis.

\section{Pengujian Asumsik Klasik}

Uji yang dilakukan sebelum pemprosesan data regresi (baik sederhana maupun berganda) agar persamaan yang dihasilkan memenuhi kaidah Best Linear Unbias Estimation. Dengan tujuan untuk memberikan kepastian bahwa persamaan regresi yang didapatkan memiliki ketepatan dalam estimasi, tidak bias dan konsisten (Gunawan, 2018). Uji asumsi klasik tediri dari uji normalitas, autokorelasi, heteroskedastisitas dan multikolinieritas.

\section{Analisis Regresi Berganda}

Regresi yang memiliki satu variabel dependen dan dua atau lebih variabel indpenden bertujuan untuk mengukur pengaruh dari variabel bebas terhadap variabel terikat yang dirumuskan sebagai berikut (Sugiyono, 2014):

$$
Y(R O A, R O E)=a+b 1 X 1+b 2 X 2+b 3 X 3+e
$$

dimana :

$$
\begin{array}{ll}
\mathrm{Y} & =\text { profitabilitas (ROA, } \mathrm{ROE}) \\
\mathrm{a} & =\text { Konstanta. } \\
\mathrm{b} 1 \mathrm{~b} 2 \mathrm{~b} 3 & =\text { Koefisien regresi variabel terikat. } \\
\mathrm{X} 1 & =\text { Zakat perbankan. } \\
\mathrm{X} 2 & =\text { Ukuran Perusahaan } \\
\mathrm{X} 3 & =\text { Islamic Social Responsibility. } \\
\mathrm{e} & =\text { Residual atau preduction error. }
\end{array}
$$

\section{Koefisien Determinasi}

Nilai koefisien determinan adalah nol dan satu. Nilai $R^{2}$ yang kecil berarti kemampuan variabelvariabel dependen amat terbatas. Dan sebaliknya jika nilai $R^{2}$ yang mendekati satu berarti variabelvariabel independen memberikan hampir semua informasi yang dibutuhkan untuk memprediksi variabel-variabel dependen (Ghozali, 2011).

\section{Pengujian Hipotesis}

Pengujian yang dilakukan dalam penelitian ini menggunakan uji $\mathrm{t}$ dan uji $\mathrm{F}$. dalam uji $\mathrm{t}$ digunakan untuk mengetahui pengaruh variabel independen sedangkan uji $\mathrm{F}$ untuk melihat pengaruh dari variabel $\mathrm{X}$ secara bersama-sama terhadap variabel $Y$.

\section{Hasil dan Pembahasan}

Kriteria yang terpenuhi dalam penelitian ini adalah 10 sampel dari 14 BUS di Indonesia yaitu Bank Muamalat Indonesia, Bank Victoria syariah, BRISyariah, Bank Jabar Banten Syariah, BNI Syariah, BSM, Bank Mega Syariah, BCA Syariah, Bank Syariah Bukopin dan BPDSyariah. Analisis Deskriptif Statistik memberikan gambaran mengenai karakteristik data variabel dengan menggunakan data sekunder dari laporan keuangan BUS yang berbentuk Time Series berupa data tahunan dari 2016 sampai 2019. Berikut ini hasil analisis deskriptif data pada tabel 2: 
Tabel 2. Analisis Deskriptif statistik

\begin{tabular}{lrrrrr}
\multicolumn{7}{c}{ Descriptive Statistics } \\
\hline & N & Minimum & Maximum & \multicolumn{1}{c}{ Mean } & Std. Deviation \\
\hline Pengeluaran Zakat & 40 & 0 & 494345000 & 32273252.95 & 79762858.502 \\
Perusahaan & 40 & 20.31 & 25.44 & 23.1625 & 1.41810 \\
Ukuran Perusahaan & 40 & .34 & .87 & .6782 & .13570 \\
IRS & 40 & -10.77 & 5.50 & -.1275 & 3.39910 \\
ROA & 40 & .00 & .47 & .0669 & .10019 \\
ROE & 40 & .00 & & & \\
Valid N (listwise) & 40 & & & &
\end{tabular}

Dari tabel diatas dapat disimpulkan bahwa pengeluaran zakat perusahaah memiliki nilai rata-rata 32273252.95 dengan standar deviasi sebesar 79762858.502 yang lebih besar dari nilai mean yang berarti memiliki variasi yang besar.Ukuran perusahaan dengan mean 23.1625 dengan standar deviasi 1.41810 lebih kecil dari nilai rata-rat yng berate memiliki variasi yang lebih kecil, ISR yang mempunyai nilai rata-rata 0.6782 dengan standar deviasi 0.13570 lebih besar dari mean yang berarti memiliki variasi yang besar. ROA yang mempunyai nilai ratarata -0.1275 dengan standar deviasi 3.39910 lebih besar dari mean yang berarti memiliki variasi yang besar sedangkan ROE memiliki nilai rata-rata sebesar 0,069 dan standar deviasi atau simpangan baku adalah sebesar 0,10019 lebih besar dari mean yang berarti bahwa memiliki variasi yang besar.

\section{Pengujian Asumsi Klasik Uji Normalitas}
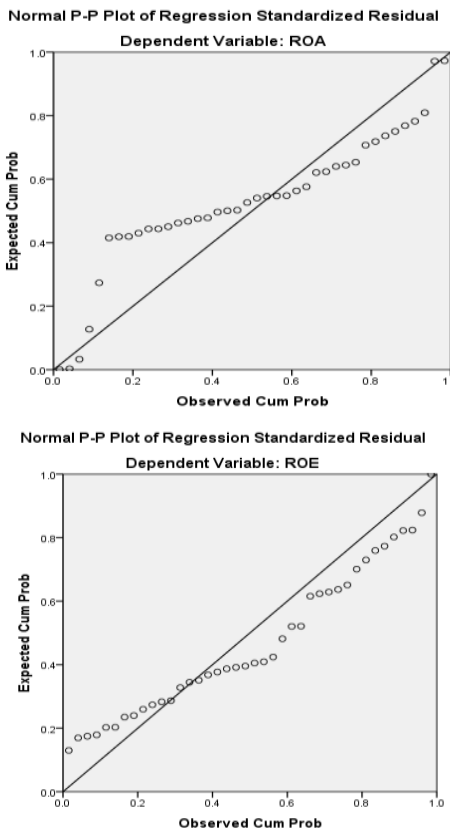

Gambar 1. Grafik Normal Probability Plot

Dilihat dari gambar 1 grafik Normal Probability Plot diatas, maka dapat disimpulkan bahwa data penelitian terdistribusi normal, hal ini disebabkan karena data ploting(titik-titik) yang mengambarkan data mengikuti garis diagonal.

\section{Uji Multikolinearitas}

Pengujian ini dilakukan dengan melihat nilai Tolerance dan VIF pada tabel 3:

Tabel 3 hasil Uji Multokolinearitas

\begin{tabular}{lcc}
\hline \multicolumn{1}{c}{ Variabel } & Tolerance & VIF \\
\hline Pengeluaran Zakat Perusahan & 0,991 & 1.009 \\
Ukuran Perusahaan & 0,985 & 1.015 \\
ISR & 0,979 & 1.021 \\
\hline
\end{tabular}

Nilai tolerance di tabel diatas lebih besar dari 0,1 maka dapat disimpulkan bahwa tidak ada multikolenearitas antar variabel independen. Begitu juga dengan nilai VIF lebih kecil dari 10 sehingga tidak terjadi multikolenieritas.

\section{Uji Heteroskedastisitas}

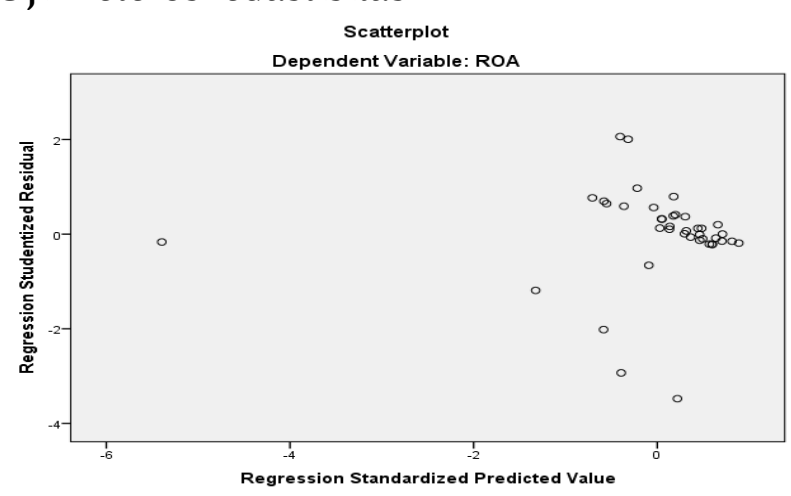

Gambar 2. Uji Heteroskedastisitas

\section{Uji Autokorelasi}

Hasil uji autokorelasi terlihat pada tabel Model Summary memperlihatkan nilai dari DurbinWatson (d) nilai tersebut akan digunakan untuk menguji autokorelasi yang bertujuan untuk menguji apakah dalam suatu model regresi linear terdapat korelasi antara kesalahan pengganggu pada periode $t$ dengan nilai $t-1$ pada tabel 4 berikut:

Tabel 4 Uji Autokorelasi

\begin{tabular}{|c|c|c|c|c|c|}
\hline \multicolumn{6}{|c|}{ Model Summary ${ }^{\mathrm{b}}$} \\
\hline Model & $\mathrm{R}$ & R Square & $\begin{array}{c}\text { Adjusted R } \\
\text { Square }\end{array}$ & $\begin{array}{l}\text { Std. Error of } \\
\text { the Estimate }\end{array}$ & $\begin{array}{l}\text { Durbin- } \\
\text { Watson }\end{array}$ \\
\hline 1 & $.806^{\mathrm{a}}$ & 649 & .620 & .06176 & 2.04 \\
\hline
\end{tabular}

Berdasarkan hasil uji diatas diketahui nilai DW pada model regresi adalah sebesar 2,043. Nilai DW tersebut berada di antara du $(1,599)<$ DW $(2,043)<4$-du $(2,401)$. Maka dapat disimpulkan bahwa tidak terdapat genjala atau masalah 
autokorelasi sehingga analisis regresi linear dapat dilanjutkan.

\section{Analisis Regresi Linier Berganda}

Model Persamaan regresi linear berganda dalam penelitian digunakan untuk mengetahui pengaruh penegluaran zakat, ukuran perusahaan dan ISR terhdap Probfitabilitas (ROA dan ROE) dengan hasil sebagai berikut:

Tabel 5. Hasil Analisis Regresi Linier

\begin{tabular}{|c|c|c|c|c|c|c|c|}
\hline & & $\mathrm{Be}$ & $\begin{array}{l}\text { rganda } \\
\text { Coefficients }^{2}\end{array}$ & & & & \\
\hline Model & $\begin{array}{l}\text { Unstandar } \\
\text { Coefficic }\end{array}$ & lized & $\begin{array}{l}\text { Standardized } \\
\text { Coefficients }\end{array}$ & $\mathrm{T}$ & Sig. & Collinearity & Statistics \\
\hline & B & $\begin{array}{l}\text { Std. } \\
\text { Error }\end{array}$ & & & & Tolerance & VIF \\
\hline $\begin{array}{l}\text { (Constant) } \\
\text { Pengeluaran }\end{array}$ & -.130 & .165 & & -.789 & .435 & & \\
\hline $\begin{array}{l}\text { Zakat } \\
\text { 1 Perusahaan }\end{array}$ & $1.011 \mathrm{E}-009$ & .000 & .805 & 8.120 & .000 & 991 & 1.009 \\
\hline $\begin{array}{l}\text { Ukuran } \\
\text { Perusahaan }\end{array}$ & .007 & .007 & .095 & .958 & .344 & .985 & 1.015 \\
\hline IRS & .013 & .074 & .017 & .172 & .864 & .979 & 1.021 \\
\hline
\end{tabular}

a. Analisis regresi berganda pada tabel di atas diperoleh koefisien untuk variabel bebas $\mathrm{X} 1=1.011 \mathrm{E}-009, \mathrm{X} 2=0,007$ dan $\mathrm{X} 3=$ 0,013 dengan konstanta sebesar -,130. Nilai konstanta bernilai $-0,013$ dengan nilai negatif. Hal ini menunjukkan bahwa apabila variabel zakat perbanka, Ukuran Perusahaan dan ISR sama dengan nol, maka Profitabilitas sebesar -0,130

b. Koefisien regresi variabel pengeluaran zakat perbankan (b1) sebesar 1.011E-009 dengan nilai positif. Hal ini menunjukkan bahwa setiap kenaikan zakat perbakan sebesar $1 \%$ maka akan memberikan dampak terhadap peningkatan Profitabilitas sebesar 1.011E-009 dengan asumsi variabel lain konstanta adalah nol (0).

c. Koefisien regresi variabel Ukuran Perusahaan (b2) sebesar 0,007 dengan nilai positif. Hal ini menunjukkan bahwa setiap peningkatan ukuran perusahaan sebesar $1 \%$, maka akan memberikan dampak peningkatan terhadap profitabilitas sebesar 0,007 dengan asumsi variabel lain konstanta adalah nol (0).

d. Koefisien regresi variabel ISR (b3) sebesar 0,013 dengan nilai positif. Hal ini menunjukkan bahwa setiap peningkatan ISR sebesar 1\%, maka akan memberikan dampak peningkatan terhadap Profitabilitas sebesar 0,13 dengan asumsi variabel lain konstanta adalah nol (0).

\section{Uji Koefesien Determinan $\left(\mathbf{R}^{2}\right)$}

Koefisien Determinan digunakan untuk mengetahui seberapa besar kemampuan variabel bebas (independen) dalam menerangkan variabel terikat (dependen). Nilai determinasi ditentukan dengan nilai Adjusted R. Square.

Tabel 6. Hasil Uji Koefesien Determinan

\begin{tabular}{|c|c|c|c|c|c|}
\hline \multicolumn{6}{|c|}{ Model Summary ${ }^{b}$} \\
\hline Model & $\mathrm{R}$ & R Square & $\begin{array}{c}\text { Adjusted R } \\
\text { Square }\end{array}$ & $\begin{array}{l}\text { Std. Error of } \\
\text { the Estimate }\end{array}$ & $\begin{array}{l}\text { Durbin- } \\
\text { Watson }\end{array}$ \\
\hline 1 & $.806^{2}$ & .649 & .620 & .06176 & 2.043 \\
\hline
\end{tabular}

Tabel 6 pada R-Square sebesar 0,649 yang berarti sebesar $64,9 \%$ profitabilitas dapat dijelaskan oleh komposisi ketiga variabel independen yaitu pengeluaran zakat, ukuran perusahaan dan ISR. sedangkan 35,1 \% dijelaskan oleh variabel lain yang tidak terobservasi dalam penelitian ini. Jadi dapat disimpulkan bawah besarnya pengaruh secara simultan antara pengeluaran zakat perbankan, ukuran perusahaan dan ISR terhadap Profitabilitas adalah sebesar $64,9 \%$. Sedangkan untuk besarnya pengaruh secara parsial antara pengeluran zakat perbankan, ukuran perusahaan dan ISR terhadap profitabilitas.

\section{Uji Simultan (Uji Statistik F)}

Uji $\mathrm{F}$ digunakan untuk menunjukkan pengaruh variabel independen terhadap variabel dependen secara simultan atau secara bersama-sama. Dengan kriteria pengambilan keputusan jika $\mathrm{F}$ hitung $>\mathrm{F}$ tabel maka $\mathrm{H}_{0}$ ditolak dan $\mathrm{H}_{1}$ diterima sehingga dapat disimpulkan bahwa variabel independen berpengaruh secara simultan terhadap variabel

\begin{tabular}{llrrrrr}
\multicolumn{7}{c}{ Tabel 7. Uji F } \\
ANOvA \\
\multicolumn{7}{c}{ Model }
\end{tabular}

Tabel 7 diketahui bahwa nilai Fhitung sebesar 22,205 lebih besar dari Ftabel sebesar 3,28. Sedangkan nilai sig. (probabilitas) sebesar 0,000 nilai probabilitas tersebut lebih kecil dari 0,05, sehingga dapat disimpulkan maka $\mathrm{H}_{0}$ ditolak dan $\mathrm{H}_{1}$ diterima. Dengan demikian ketiga variabel dalam penelitian ini secara simultan berpengaruh positif dan signifikan terhadap Profitabilitas (Y). 


\section{Uji PArsial (Uji T)}

Uji-t digunakan untuk menunjukkan pengujian yang dilakukan untuk melihat pengaruh dari setiap variabel independen terhadap dependen. Ketentuan pengambilan keputusan pada Uji-t apabila $t_{\text {hitung }}>t_{\text {tabel}}$, maka $\mathrm{H}_{0}$ ditolak dan dapat disimpulkan bahwa variabel independen secara parsial berpengaruh terhadap variabel dependen dan begitu pula sebaliknya jika $t_{\text {hitung }}<t_{\text {tabel }}$ maka $\mathrm{H}_{1}$ ditolak dan $\mathrm{H}_{0}$ diterima artinya variabel independen secara parsial tidak berpengaruh terhadap variabel dependen.

Hasil uji T untuk variabel pengeluaran zakat (X1) diperoleh hasil thitung 8,120 lebih besar dari ttabel sebesar 2,037, dengan nilai sig. 0,000. Nilai sig. lebih kecil dari 0,05 maka $\mathrm{H0}$ ditolak H1 diterima. dapat dikatakan bahwa pengeluaran zakat (X1) secara parsial berpangaruh positif dan signifikan terhadap profitabilitas (Y). ukuran perusahaan $\left(\mathrm{X}_{2}\right)$ hasil yang didapat thitung 0,958 lebih besar dari ttabel sebesar 2,037, dengan nilai sig. 0,344. Nilai sig. lebih besar dari 0,05 maka H1 ditolak H0 diterima. dapat dijelaskan bahwa ukuran perusahaan $\left(\mathrm{X}_{2}\right)$ secara parsial tidak berpangaruh terhadap profitabilitas $(\mathrm{Y})$. variabel ISR (X3) diperoleh hasil thitung 0,172 lebih kecil dari ttabel sebesar 2,037, sedangkan nilai sig. (probalitas) sebesar 0,864. Nilai sig. (probalitas) lebih kecil dari 0,05 maka H0 diterima H1 ditolak. Dengan demikian bahwa ISR $\left(\mathrm{X}_{3}\right)$ secara parsial tidak berpengaruh dan signifikan terhadap profitabilitas (Y) pada BUS di Indonesia.

\section{Pembahasan}

Dilihat dari uji simultan pengeluaran zakat perbakan, ukuran perusahaan dan Islamic Corporate Social Responsibility terhadap profitabilitas pada Bank Umum Syariah periode 2016-2019 menunjukkan bahwa nilai Fhitung sebesar 22,205 lebih besar dari Ftabel sebesar 3,28. Dengan nilai signifikan sebesar 0,000 lebih kecil dari 0,05, sehingga dapat disimpulkan maka $\mathrm{H}_{0}$ ditolak dan $\mathrm{Ha}_{1}$ diterima. Yng artinya secara simultan variabel independen berpengaruh terhadap variabel dependen. Hasil uji parsial untuk pengeluaran zakat (X1) berpengaruh positif dan signifikan terhadap Profitabilitas pada BUS periode 2016-2019. Dengan analisi data yang diperoleh hasil uji $\mathrm{t}$ adalah sebesar thitung 8,120 lebih besar dari ttabel sebesar 2,037, sedangkan nilai sig. (probalitas) sebesar 0,000 .
Nilai sig. (probabilitas) lebih kecil dari 0,05 maka H0 ditolak Ha diterima.

Zakat merupakan salah satu konsep dalam perusahaan yang sangat melekat pada perbankan syariah dimana menjalankan operasional perusahaan tidak semata-mata hanya untuk mendapatkan keuntungan yang ditargetkan oleh manajemen, akan tetapi untuk semua aspek baik diluar maupun didalam perusahaan perlu diperhatikan. Perusahaan yang memiliki pendapatan mencapai nisab yaitu yang telah memenuhi syarat untuk mengelurakan zakat maka wajib untuk mengeluarkan zakat perusahaannya. Semakin tinggi pendapatan suatu perusahan pada satu periode terdapat $2,5 \%$ hak orang lain yang harus dikeluarkan zakatnya. Hasil ini sejalan dengan penelitian yang dilakukan oleh (Amirah dan Budi, 2014) menemukan hasil positif yang signifikan terkait hubungan zakat dengan kinerja keuangan perbankan syariah. Penelitiannya dilakukan di Indonesia dengan periode pengamatan 3 tahun yaitu dari 2009-2012.

Hasil untuk variabel ukuran perusahaan (X2) tidak berpengaruh dan signifikan terhadap Profitabilitas pada BUS periode 2016-2019. Dimana analisis data yang diperoleh hasil uji $t$ adalah sebesar thitung 0,958 lebih kecil dari ttabel sebesar 2,037, sedangkan nilai signifikan sebesar 0,344 . Yang berarti lebih besar dari 0,05 maka $\mathrm{H} 0$ diterima $\mathrm{Ha}$ ditolak. Ukuran perusahaan yang besar belum tentu mendapatkan laba yang maksimal, karena perusahan besar akan mengeluarkan biaya operasional lebih besar dibandingkan perusahaan yang ukuran lebih kecil. Hasil ini sejalan dengan penelitian yang dilakukan oleh (Rahayu, Cahyati, dan Dewi, 2014) hasil yang diperoleh tidak berpengaruh terhadap CSR, karena ukuran perusahaan tidah hanya dilihat total aset, tetapi bisa juga dari rasio-rasio keuangan lain untuk menghasilkan laba yang tinggi.

Hasil pengujian menjelaskan bahwa ISR tidak berpegaruh dan signifikan terhadap Profitabilitas Bank Umum Syariah periode 2016-2019. variabel ISR diperoleh hasil thitung 0,172 lebih kecil dari ttabel sebesar 2,037, sedangkan nilai sig. (probalitas) sebesar 0,864. Nilai sig. (probalitas) lebih besar dari 0,05. Ini menunjukkan bahwa naik turunya jumlah ISR yang dikeluarkan oleh BUS tidak berpengaruh terhadap Profitabiltas. Hal ini 
dikarenakan untuk memperoleh manfaat dari ISR yang dilaksanakan guna mendapatkan value atau nilai lebih bagi perusahaan memerlukan waktu yang lebih panjang, misalkan kegiatan ISR dalam program beasiswa bagi pelajar yang berprestasi maupun kurang mampu, perusahaan tidak akan mendapatkan keuntungan secara langsung dalam waktu relatif singkat. Selain itu, proses penyaluran dana ISR ini juga menjadi salah satu alasan ISR disalurkan belum optimal, contohnya saja saat ini banyak dari Bank Umum Syariah peyaluran dana ISR kelola oleh instansi terkait misal BNI Syariah disalurkan melalui Yayasan Hasanah, Bank Muamalat Indonesia melalui Baitul Mal Muamalat, sehingga penyaluran kepada masyarakat umum tidak sesuai sasaran dalam hal ini, yang mendapatkan bantuan ISR hanya sekelompok tertentu yang telah menjadi calon penerimaan ISR setiap tahunnya.

Hasil penelitian ini bertolak belakang dengan penelitian mengenai ISR terhadap kinerja perusahan yangt telah dilakukan oleh (Sari dkk, 2013) bahwa pengunggkapan i-CSR berpengaruh positif dan signifikan terhadap kinerja keuangan. Ini berarti semakin tinggi pegungkapan i-CSR, semakin tinggi kinerja keuangan. Namum sejalan dengan hasil penelitian (Sidik dan Reskino, 2016) yang mengatakan bahwa Islamic Social Responsibility tidak memiliki pengaruh yang signifikan terhadap kinerja perusahaan.

\section{Kesimpulan}

1. Pengeluaran Zakat Perusahaan secara parsial berpengaruh positif dan signifikan terhadap profitabilitas pada BUS di Indonesia.

2. Ukuran perusahaan secara parsial tidak berpengaruh dan signifikan terhadap profitabilitas pada BUS di Indonesia.

3. Islamic Social Responsibility secara parsial tidak berpengaruh dan signifikan terhadap profitabilitas pada BUS di Indonesia.

\section{Daftar Pustaka}

Amirah \& Raharjo, Budi. (2014). Pengaruh Alokasi Dana Zakat Terhadap Kinerja Keuangan Perbankan Syariah. In Prosiding- Seminar Nasional dan 1st call for Syariah Paper (Sancall). Universitas Muhammadiyah Surakarta.

Arifin, Johan \& Wardani, Eke Ayu. (2016). Pengaruh Profitabilitas, Ukuran Perusahaan dan Leverage Terhadap Pengukapan Islamic Sosial Reporting Pada Perusahaan: Studi Kasus Pada Perusahaan yang Tercatat di Jakarta Islamic Index. N.J Bennet Volume 20. Nomor 1, 27.

Arikunto, Suharsimi. (2016). Prosedur Penelitian Suatu Pendekatan Praktik. Jakarta: Rineka Cipta.

Eliana, Nurhayati \& Ayumiati (2020). Pengaruh Ukuran perusahaan, Leverage dan Profitabilitas terhadap Penerapan Good Corporate Governance Bisnis Syariah Bus di Indonesia. Jurnal Akuntansi Berkelanjutan Indonesia (JABI). Vol 3, No.2 ISSN 2615-7896. hal 182-192.

Falikhatum, \& Assegaf. (2012). Bank Syariah di Indonesia: Ketaatan Pada Prinsip-Pinsip Syariah dan Kesehatan Financial. Jurnal Accounting and Management (CBAM) 1(1): 245-254.

Firmansyah, Irman. (2013). Pengaruh Profitabilitas Terhadap Pengeluaran Zakat Pada Bank Umum Syariah Di Indonesia Dengan Ukuran Perusahaan sebagai Variabel Moderasi. Jurnal Liquidity. Vol. 2, No.2, hlm.110-116.

Ghozali, Imam. (2011). Aplikasi Analisis Multivariat dengan Program IBM SPSS 21 Update PLS Regresi. Semarang: Universitas Diponegoro. 
Gunawan, Ce. (2018). Mahir Menguasai SPSS: Mudah Mengolah Data Dengan IBM SPSS Statistic 25. Yogyakarta: Deepublish.

Ilmi, Muhammad Bahrul. (2011). Pengrauh Zakat sebagai Tanggungjawab Sosial Perusahaan terhadap Kinerja Perusahaan pada Bank Umum Syariah di Indonesia. Jurnal Graduasi Vo. 26, 11.

Masruroh, Nikmatulla. (2015). Zakat di Perbankan Syariah. Al-Masyraf Vol. 2 No.1 13.

Rahayu, Ribut Sri \& Cahyati, Ari Dewi. (2014). Faktor-faktor yang Mempengaruhi Pengungkapan Corporate Social Resposibility (CSR) pada Perbankan Syariah. JRAK Vol.5, No.2, Hal 74-87.

Sari, Ni Luh Kade Merta \& Suaryana, I Gusti Ngurah Agung. (2013). Pengaruh Pengungkapan CSR Terhadap Kinerja Keuangan dengan Kepemilikan Asing. EJurnal Akuntansi Universitas Udayana 3.2. hal 248-247. ISSN: 2302-8556.
Septian, Rika Amelia, \& DP, Emrinaldi. Nur. (2012). Pengaruh Implementasi Corporate Social Responsibility Terhadap Profitabilitas Perusahaan (Studi kasus pada Peruahaan Manufaktur yang Listing BEI 2007-2009). Pekbis Jurnal, Vol. 4, No2, 84.

Sidik, Ichwan \& Reskino. (2016). Pengaruh Zakat dan ICSR terhadap Reputasi dan Kinerja. Simposium Nasional Akuntansi XIX. Lampung.

Sugiyono. (2014). Metode Penelitian Kuantitatif, Kualitatif dan R\&D. Bandung: Alfabeta.

Syamsuddin, Lukman. (2009). Manajemen Keuangan Perusahaan: Konsep Aplikasi dalam: Perencanaan, Pengawasan, dan Pengambilan Keputusan. Jakarta: Rajawali Pers. 